\title{
Recent patent applications in induced pluripotent stem (iPS) cells
}

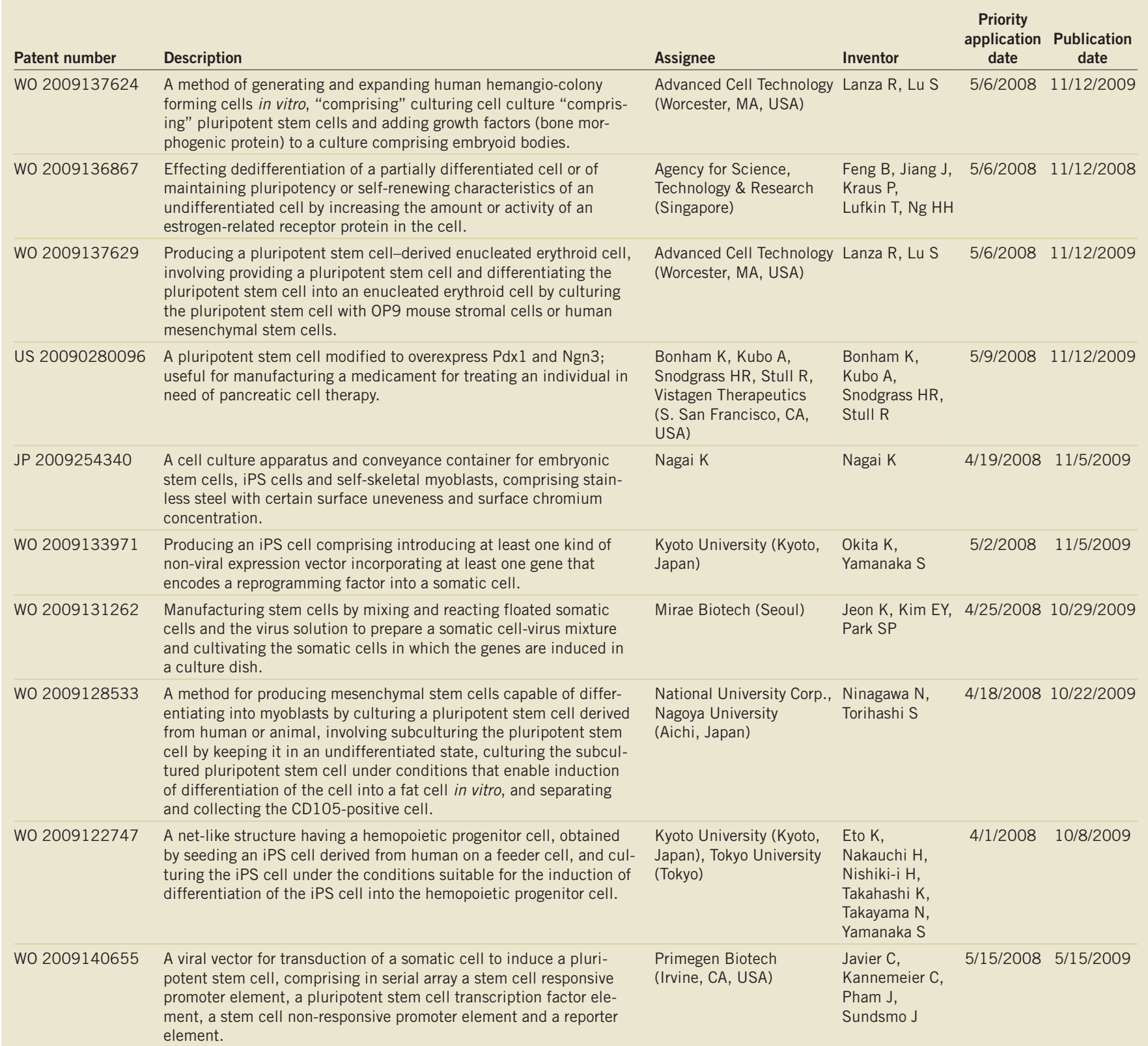

Source: Thomson Scientific Search Service. The status of each application is slightly different from country to country. For further details, contact Thomson Scientific, 1800 Diagonal Road, Suite 250, Alexandria, Virginia 22314, USA. Tel: 1 (800) 337-9368 (http://www.thomson.com/scientific). 